\title{
Ensuring energy security in ASEAN countries: Current trends and major challenges
}

\author{
Sergey Senderov ${ }^{1 *}$, Sergey Vorobev ${ }^{1}$ \\ ${ }^{1}$ Melentiev Energy Systems Institute, 130 Lermontov str., Irkutsk, Russia
}

\begin{abstract}
The paper discusses the issues of formation of future challenges to energy security of the ASEAN countries in the period up to 2035. The article gives examples of strategic threats to the energy security of Russia. The opportunities to meet future demand for primary energy for individual countries of ASEAN and the whole region are discussed.
\end{abstract}

\section{Introduction}

Energy security (ES) in terms of economy and population of a country is understood as the condition of being protected against a threat of shortage of economically accessible fuel and energy resources (FER) of acceptable quality and against a threat of stable fuel and energy supply disruption. For normal operation of the fuel and energy complex (FEC) this condition of being protected implies, in a long-term context, satisfaction of the country's demand for electricity, thermal energy, boiler and furnace fuel and motor fuel. During extraordinary situations, for example, heavy emergencies at FEC facilities, the condition of being protected supposes guaranteed satisfaction of the minimum necessary energy demand of the country's vitally important consumers including those from the social sphere.

For the countries with scarce fuel and energy resources (Japan, Korea, Thailand, etc.) an important component of ES is reliability and guarantee of FER supply, and for the countries that are more or less provided with the resources (the USA, Great Britain, China, Vietnam can also be referred to as these countries) - it is energy independence: capability to cope with loss/decrease in FER supplies using their own resources.

Analysis of the current status and trends of Russia's FEC development reveals a number of strategic threats to ES even for Russia - the country which is provided with energy resources quite well. The notion of "strategic threats to the national ES" should be understood as the threats whose realization may cause a persistent and long-term shortage of energy in the country, which can retard economic growth of the country, lead to stagnation or deterioration of its social and economic situation. These strategic threats relate to such issues as: the lack of investment in the energy sector; high energy intensity of the economy; high wear equipment in the energy sector; the dominant role of natural gas in the European part of the country, etc.

\footnotetext{
* Corresponding author: ssm@isem.irk.ru
} 
Russia does not have any particular problems of energy independence; it has enough reserves of energy resources now and in the future. What is most important to ensure energy security in the countries or regions of the world where energy resources are scarce?

Let's look at the situation with the prospects for energy security and the development of green energy in the ASEAN countries.

\section{The share of nuclear and renewable energy sources in primary energy consumption in ASEAN}

At the time in 2009-2016 the share of renewable sources, including hydro energy, in primary energy consumption of the world changed from $7,8 \%$ up to $10,0 \%$ mainly due to the increase in the use of other renewable resources. The data demonstrate the following situation in the world (Table 1).

Table 1. The share of renewable energy sources in primary energy consumption in the world, $[1,2]$

\begin{tabular}{|c|c|c|c|c|c|}
\hline & $\begin{array}{l}\text { Primary } \\
\text { energy }\end{array}$ & Hydro & $\begin{array}{l}\text { Other renewable } \\
\text { (without bioenergy) }\end{array}$ & $\begin{array}{l}\text { Share of } \\
\text { hydro }\end{array}$ & $\begin{array}{l}\text { Share of } \\
\text { renew. in } \\
\text { Total }\end{array}$ \\
\cline { 2 - 7 } & \multicolumn{7}{|c|}{ mtoe } & \multicolumn{2}{c|}{$\%$} \\
\hline 2009 & 11326 & 738 & 143 & 6,5 & 7,8 \\
\hline 2010 & 11956 & 784 & 168 & 6,6 & 8,0 \\
\hline 2011 & 12232 & 796 & 205 & 6,5 & 8,2 \\
\hline 2012 & 12483 & 834 & 241 & 6,7 & 8,6 \\
\hline 2013 & 12730 & 856 & 279 & 6,7 & 8,9 \\
\hline 2015 & 13105 & 883 & 366 & 6,7 & 9,5 \\
\hline 2016 & 13276 & 910 & 419 & 6,8 & 10,0 \\
\hline
\end{tabular}

The same situation is observed in the world regions. For example for the entire North America this share increased only by $1.3 \%$ (from $13.4 \%$ to $14.7 \%$ ), for Europe and Eurasia - by $1.4 \%$ (from $16.7 \%$ to $18.1 \%$ ). In the regions of South and Central America, Middle East, Africa and APR this share did not change at all and made up 28.3\%, 0.4\%, 7.3\% and 9\%, respectively. The data [1] demonstrate the following situation in the largest ASEAN countries (Table 2).

Table 2. The share of renewable energy sources in primary energy consumption in ASEAN, $[1,2]$

\begin{tabular}{|c|c|c|c|c|c|}
\hline & $\begin{array}{l}\text { Primary } \\
\text { energy }\end{array}$ & Hydro & $\begin{array}{l}\text { Other } \\
\text { renewable }\end{array}$ & $\begin{array}{l}\text { Share of } \\
\text { hydro }\end{array}$ & $\begin{array}{l}\text { Share of renew. } \\
\text { in Total }\end{array}$ \\
\hline & \multicolumn{3}{|c|}{ mtoe } & \multicolumn{2}{|r|}{$\%$} \\
\hline 2009 & 485 & 14,8 & 128,9 & 3,1 & 29,6 \\
\hline 2010 & 523 & 14,8 & 140,2 & 2,8 & 29,6 \\
\hline 2011 & 549 & 18 & 139,2 & 3,3 & 28,6 \\
\hline 2012 & 568 & 21,2 & 140,1 & 3,7 & 28,4 \\
\hline 2013 & 594 & 21,3 & 143,7 & 3,6 & 27,8 \\
\hline 2015 & 562 & 22,4 & 144,8 & 3,9 & 29,7 \\
\hline 2016 & 589 & 24,1 & 149,1 & 4,1 & 29,4 \\
\hline
\end{tabular}

Analysis of Table 2 shows that, compared with the global trends (also not very fast, 1\% for 7 years) the process of change in the share of renewable energy in total energy 
consumption has a reverse trend. Over the past seven years, this share decreased by $0,2 \%$. In general, the decrease can be explained by a gradual increase in the share of centralized power and correspondingly by reducing the share of biomass use by individual consumers in rural areas.

Now we can consider how this process has been in major ASEAN countries in the past five years, Table 3 .

Table 3. The share of renewable energy sources in primary energy consumption in largest ASEAN countries, [1,2]

\begin{tabular}{|c|c|c|c|c|c|c|c|}
\hline & 2009 & 2010 & 2011 & 2012 & 2013 & 2015 & 2016 \\
\hline \multicolumn{8}{|c|}{ Thailand } \\
\hline Primary energy, mtoe & 95,9 & 102,4 & 106,4 & 113,7 & 115,7 & 121,8 & 123,8 \\
\hline Hydro \& oth.ren., mtoe & 22,1 & 22,4 & 22,7 & 23,1 & 23,5 & 23,7 & 24,1 \\
\hline Share of renewable, \% & 18,7 & 18,3 & 17,8 & 17,5 & 17,2 & 17,5 & 17,9 \\
\hline \multicolumn{8}{|c|}{ Malaysia } \\
\hline Primary energy, mtoe & 73,6 & 72,4 & 79,8 & 83,2 & 89,2 & 93,8 & 99,5 \\
\hline Hydro \& oth.ren., mtoe & 1,9 & 1,7 & 2,2 & 2,4 & 2,9 & 3,8 & 4,5 \\
\hline Share of renewable, \% & 2,5 & 2,3 & 2,7 & 2,8 & 3,2 & 4,1 & 4,5 \\
\hline \multicolumn{8}{|c|}{ Singapore } \\
\hline Primary energy, mtoe & 64,3 & 69,0 & 71,7 & 72,0 & 74,1 & 81,0 & 84,1 \\
\hline Hydro \& oth.ren., mtoe & 0,1 & 0,1 & 0,1 & 0,1 & 0,2 & 0,2 & 0,2 \\
\hline Share of renewable, \% & 0,2 & 0,1 & 0,1 & 0,1 & 0,3 & 0,2 & 0,2 \\
\hline \multicolumn{8}{|c|}{ Indonesia } \\
\hline Primary energy, mtoe & 200,3 & 206,1 & 211,9 & 217,2 & 222,3 & 224,7 & 235,0 \\
\hline Hydro \& oth.ren., mtoe & 54,8 & 55,9 & 57,1 & 58,3 & 59,5 & 59,9 & 60,0 \\
\hline Share of renewable, \% & 27,3 & 27,1 & 26,9 & 26,8 & 26,8 & 26,6 & 25,5 \\
\hline \multicolumn{8}{|c|}{ Vietnam } \\
\hline Primary energy, mtoe & 39,3 & 44,3 & 50,3 & 52,5 & 54,8 & 63,7 & 64,8 \\
\hline Hydro \& oth.ren., mtoe & 6,8 & 6,2 & 9,3 & 12,0 & 12,9 & 12,9 & 13,8 \\
\hline Share of renewable, \% & 17,3 & 13,9 & 18,5 & 22,8 & 23,5 & 20,2 & 21,3 \\
\hline \multicolumn{8}{|c|}{ Philippines } \\
\hline Primary energy, mtoe & 33,5 & 36,7 & 39,8 & 42,8 & 46,2 & 51,7 & 57,1 \\
\hline Hydro \& oth.ren., mtoe & 15,4 & 16,0 & 16,8 & 17,5 & 18,2 & 18,7 & 20,1 \\
\hline Share of renewable, \% & 46,0 & 43,6 & 42,2 & 40,9 & 39,4 & 36,1 & 35,2 \\
\hline
\end{tabular}

In Thailand the share of renewable energy in the past seven years was decreased by $0,8 \%$. In Singapore this share has remained at the same level as that of 7 years ago. In Indonesia, it decreased by $1,8 \%$ in the Philippines decreased by $10,8 \%$. Only in Malaysia and Vietnam, this share was increased. For Vietnam, this is due to an active construction and commissioning of hydropower plants.

Comparison of data from Table 3 makes it possible to assess changes in the dependence of the largest ASEAN countries on supplies of the main types of non-renewable primary energy: coal, heavy oil, natural gas in 2009-2016 (Table 4). 
Table 4. Relative change in the values of primary energy consumption and in the average share of renewable resources in this consumption in the largest ASEAN countries

\begin{tabular}{|l|c|c|}
\hline \multirow{2}{*}{ Country } & \multicolumn{2}{|c|}{ Change 2016 over 2009, \% } \\
\cline { 2 - 3 } & $\begin{array}{l}\text { Primary energy } \\
\text { consumption }\end{array}$ & $\begin{array}{l}\text { Share of renewable } \\
\text { energy resources }\end{array}$ \\
\hline Thailand & 29,1 & $-0,8$ \\
\hline Malaysia & 35,3 & 2,6 \\
\hline Singapore & 30,7 & 0,0 \\
\hline Indonesia & 17,3 & $-1,8$ \\
\hline Vietnam & 64,8 & 4,0 \\
\hline Philippines & 70,4 & $-10,8$ \\
\hline ASEAN as a whole & $\mathbf{2 1 , 4}$ & $\mathbf{1 , 4}$ \\
\hline
\end{tabular}

Analysis of data from Table 4 shows a dynamic increase in consumption of nonrenewable primary energy in all ASEAN regions in comparison with reducing in the share of renewable energy in the total primary energy consumption.

\section{Dependence of the largest ASEAN countries on imported primary energy}

Now let us focus on the non-renewable primary energy resources consumed to produce different types of energy. Table 5-7 show how the demand of primary energy can be covered in the countries - major energy consumers in ASEAN.

\subsection{Dependence on imported natural gas}

Table 5 shows information about main existing trends concerning of the dependence of the largest ASEAN countries on imported natural gas.

Data in Table 5 show that Singapore fully depends on external supplies of natural gas, $20 \%$ is depending of Thailand. Given the production of natural gas in Brunei and Myanmar about 26 million toe in total, it is seen that the region is balanced on production and consumption of natural gas. Gas flows in the region in 2016 were supplied through the main gas pipeline from Indonesia to Singapore, from Malaysia and Myanmar to Thailand and from Brunei to Singapore. Shipments of liquefied natural gas in 2016 were carried out mainly from Qatar, Africa and Brunei.

Table 5. Dependence of the largest ASEAN countries on imported natural gas, $[1,2]$

\begin{tabular}{|l|c|c|c|c|c|c|c|c|c|c|c|}
\hline \multirow{3}{*}{ Country } & \multicolumn{4}{|c|}{ Production } & \multicolumn{4}{c|}{ Consumption } & \multicolumn{3}{c|}{ Dependence on import } \\
\cline { 2 - 11 } & 2010 & 2013 & 2016 & 2010 & 2013 & 2016 & 2010 & 2013 & 2016 \\
\cline { 2 - 11 } & \multicolumn{6}{|c|}{ Million toe } & \multicolumn{3}{c|}{$\%$} \\
\hline Thailand & 32,7 & 37,6 & 34,7 & 40,6 & 47,0 & 43,5 & 19 & 20 & 20 \\
\hline Malaysia & 58,8 & 62,1 & 66,5 & 31,6 & 30,6 & 38,7 & - & - & - \\
\hline Singapore & - & - & - & 7,6 & 9,5 & 11,3 & 100 & 100 & 100 \\
\hline Indonesia & 73,8 & 63,4 & 62,7 & 36,3 & 34,6 & 33,9 & - & - & - \\
\hline Vietnam & 8,5 & 8,8 & 9,6 & 8,5 & 8,8 & 9,6 & - & - & - \\
\hline Philippines & 3,2 & 3,0 & 3,4 & 3,2 & 3,0 & 3,4 & - & - & - \\
\hline
\end{tabular}




\subsection{Dependence on imported coal}

Table 6 shows information about main existing trends concerning of the dependence of the largest ASEAN countries on imported coal.

Table 6. Dependence of the largest ASEAN countries on imported coal, [1,2]

\begin{tabular}{|l|c|c|c|c|c|c|c|c|c|c|}
\hline \multirow{3}{*}{ Country } & \multicolumn{3}{|l|}{ Production } & \multicolumn{9}{|c|}{ Consumption } & \multicolumn{3}{l|}{ Dependence on import } \\
\cline { 2 - 11 } & 2010 & 2013 & 2016 & 2010 & 2013 & 2016 & 2010 & 2013 & 2016 \\
\cline { 2 - 11 } & \multicolumn{9}{|c|}{ Million toe } \\
\hline Thailand & 5,1 & 5,1 & 4,3 & 15,8 & 16,0 & 17,7 & 68 & 68 & 75 \\
\hline Malaysia & 1,9 & 2,0 & 2,0 & 14,8 & 17,0 & 19,9 & 87 & 88 & 90 \\
\hline Singapore & - & - & - & - & - & 0,4 & - & - & 100 \\
\hline Indonesia & 169,2 & 258,9 & 255,7 & 41,2 & 54,4 & 62,7 & - & - & - \\
\hline Vietnam & 24,6 & 23,1 & 22,0 & 13,9 & 15,9 & 21,3 & - & - & - \\
\hline Philippines & 5,2 & 5,2 & 5,2 & 7,7 & 10,5 & 13,5 & 32 & 50 & 61 \\
\hline
\end{tabular}

Data in Table 6 show that Malaysia, Singapore, Thailand and Philippines are significantly depend on external supplies of coal. At the same time, a significant excess of coal production over its consumption in Indonesia completely covers the demand for external coal supplies from these countries.

Comparison of possibilities of primary energy production and scale of their consumption by country (Table 5-6) shows the countries that depend on the external energy supplies to the greatest extent. This is Singapore. The rest of the largest ASEAN countries can be subdivided into the following groups:

- the countries that satisfy their demand for gas and coal by local resources and export them (Indonesia, Vietnam);

- the countries that partly import some resources (Thailand imports some amount of gas and coal, Malaysia - some amount of coal) but have equivalent production reserves of natural gas. Philippines partly import coal, but completely consume only its own natural gas.

On the whole, if not to consider oil fuels, the ASEAN region can be considered as energy resources self-sufficient region.

If you try to piece together the possible production of natural gas and coal, and their consumption, you can get the total picture of the dependence of the largest countries in ASEAN from these important primary energy resources.

Table 7. Dependence of the largest ASEAN countries on imported natural gas and coal

\begin{tabular}{|l|c|c|c|c|c|c|c|c|c|c|}
\hline \multirow{3}{*}{ Country } & \multicolumn{3}{|c|}{$\begin{array}{c}\text { Production gas and } \\
\text { coal }\end{array}$} & \multicolumn{3}{c|}{$\begin{array}{c}\text { Consumption gas and } \\
\text { coal }\end{array}$} & \multicolumn{3}{c|}{ Dependence on import } \\
\cline { 2 - 11 } & 2010 & 2013 & 2016 & 2010 & 2013 & 2016 & 2010 & 2013 & 2016 \\
\cline { 2 - 11 } & \multicolumn{9}{|c|}{ Million toe } & \multicolumn{3}{c|}{$\%$} \\
\hline Thailand & 37,8 & 42,7 & 39,0 & 56,4 & 63,0 & 61,2 & 33 & 33 & 36 \\
\hline Malaysia & 60,7 & 64,1 & 68,5 & 46,4 & 47,6 & 58,6 & - & - & - \\
\hline Singapore & - & - & - & 7,6 & 9,5 & 11,7 & 100 & 100 & 100 \\
\hline Indonesia & 243,0 & 322,3 & 318,4 & 77,5 & 89,0 & 96,6 & - & - & - \\
\hline Vietnam & 33,1 & 31,9 & 31,6 & 22,4 & 24,7 & 30,9 & - & - & - \\
\hline Philippines & 8,4 & 8,2 & 8,6 & 10,9 & 13,5 & 16,9 & 23 & 39 & 49 \\
\hline
\end{tabular}


Data of Table 7 show that Indonesia, Malaysia and Vietnam can be characterized as independent country in terms of primary energy consumption. Thailand, the Philippines and Singapore are in varying degrees dependent on external supplies of these kinds of energy and can't cover its energy needs from their own sources. Such situation in the Philippines is rapidly getting worse.

\subsection{Dependence on imported oil}

According to the information of the World Energy Agency [2], by 2030 consumption of primary energy in the world may increase up to 17 billion toe and in the Asian region - up to 7 billion toe. Despite this fact the anti-nuclear sentiments related to the problems of nuclear energy security, radioactive waste storage and burial are still very strong. The situation was to a great extent exacerbated after the emergency at the Fukushima NPP. Thus, the main load in the growing consumption of primary energy again falls on traditionally used gas, oil and coal.

Almost all oil in ASEAN countries after refining is used for transport purposes, therefore, we will consider the situation with the dependence of the largest ASEAN countries consuming energy on external oil supplies, Table 8.

Table 8. Dependence of the largest ASEAN countries on imported oil, $[1,2]$

\begin{tabular}{|l|c|c|c|c|c|c|c|c|c|c|}
\hline \multirow{3}{*}{ Country } & \multicolumn{3}{|c|}{ Production } & \multicolumn{3}{c|}{ Consumption } & \multicolumn{2}{c|}{ Dependence on import } \\
\cline { 2 - 11 } & 2010 & 2013 & 2016 & 2010 & 2013 & 2016 & 2010 & 2013 & 2016 \\
\cline { 2 - 10 } & \multicolumn{9}{|c|}{ Million toe } \\
\hline Thailand & 14,8 & 16,6 & 17,6 & 44,3 & 50,4 & 59,0 & 67 & 67 & 70 \\
\hline Malaysia & 32,0 & 29,6 & 32,7 & 29,3 & 31,2 & 36,3 & - & 5 & 10 \\
\hline Singapore & - & - & - & 62,8 & 65,9 & 72,2 & 100 & 100 & 100 \\
\hline Indonesia & 48,6 & 42,7 & 43,0 & 66,4 & 73,8 & 72,6 & 27 & 42 & 41 \\
\hline Vietnam & 15,3 & 17,0 & 16,0 & 15,6 & 17,4 & 20,1 & 2 & 2 & 20 \\
\hline Philippines & 1,3 & 1,2 & 1,2 & 13,2 & 13,7 & 19,9 & 90 & 91 & 94 \\
\hline
\end{tabular}

Data from Table 8 are indicative of the reliance of the largest ASEAN countries on imported oil (Singapore and Philippines are almost totally dependent). Fig. 1 shows the tendencies towards increase in the dependence of some countries and region as a whole. In previously independent of external supplies of oil Malaysia for the past 4 years the dependence on external supplies of oil increased up to $5 \%$. Also up to $42 \%$ (in one and a half) dependence on external supplies of oil has increased over the last 4 years in Indonesia.

In general, the ASEAN region is deficient in the oil and significantly depends on its external supply. Structure of net oil imports in countries that depends from external oil supply is roughly similar to structure that shown in Fig. 2 for Singapore in 2016. 


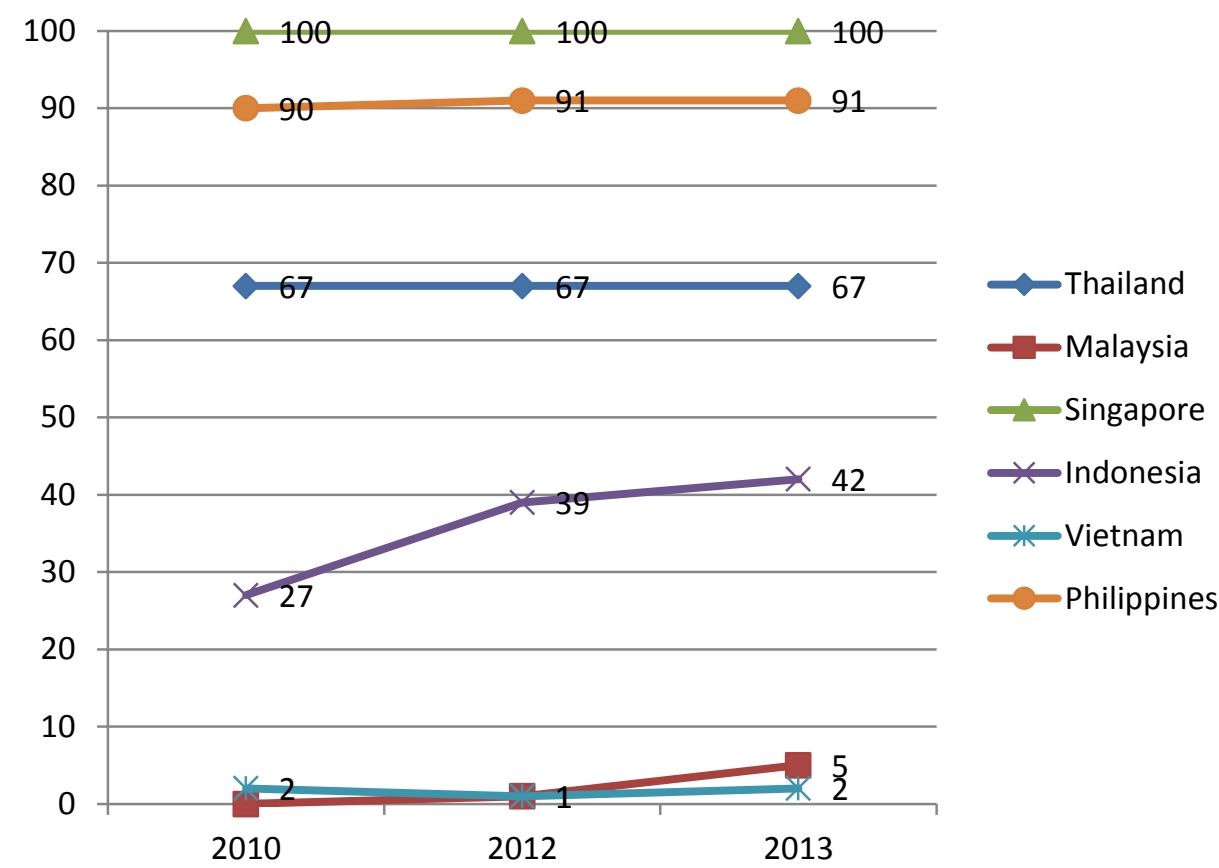

Fig.1. Change in dependence of the largest ASEAN countries on external oil supplies

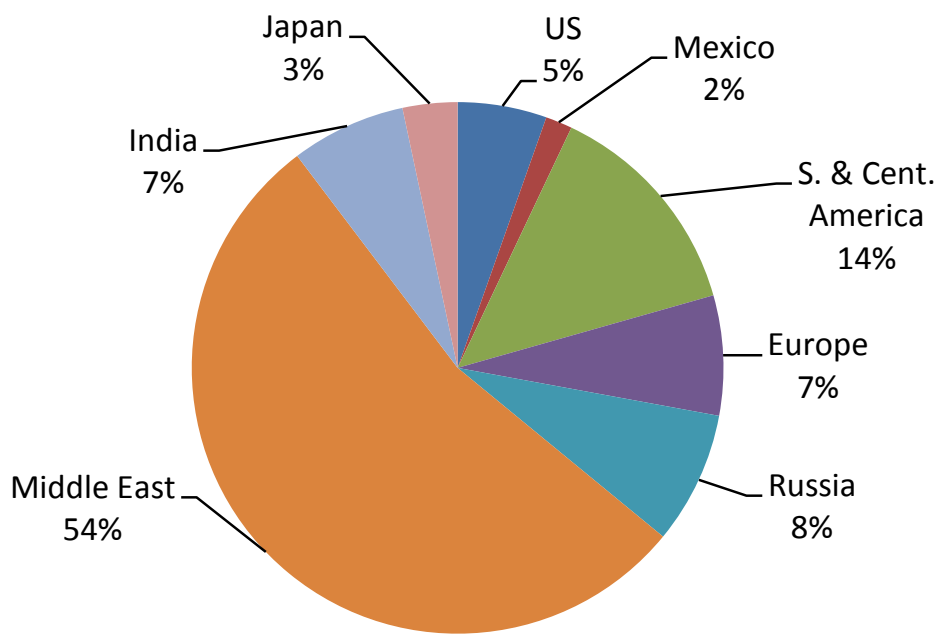

Fig. 2. Structure of Singapore's net oil import in 2016, [1]

Data of Fig. 2 show that the structure of the external oil supply to Singapore is: more than half of such deliveries made from the Middle East and the rest are more or less evenly divided between the 7 countries - oil exporters.

As seen from table 8, ASEAN countries actively increase their dependence on imported oil. This can greatly reduce the energy security of the region in the run up to 2035, when it may cause serious decline of oil production in the existing fields on the background of 
insufficient pace of development of new oil fields. IEA estimates that by 2035 the overall decline in oil production could reach about $30 \%$ of the existing oil production volumes. At the same time, according to some estimates ASEAN could become fourth largest oil importer after China, India and the countries of the EU. Region's dependence on oil by that time could double and increase to $75 \%$, and net imports may increase from 2 million barrels per day to 5 million barrels per day. Expenses of the region on oil imports could triple and reach about 250 billion US dollars in constant prices. More than $50 \%$ of this amount will likely have on Indonesia and Thailand [2].

IEA estimated proved oil reserves at the beginning of 2014 about 1.8 billion tons. At the current level of oil production, these reserves can be used for approximately 14 years.

\subsection{The main energy characteristics of the ASEAN countries}

So, we can formulate the main energy characteristics of the ASEAN countries. Based on this analysis, it is possible to comment on the main energy characteristics for each of the countries.

Indonesia is a largest energy consumer in ASEAN with significant potential for further growth in energy consumption. It is a largest exporter of coal, as well as exporter of LNG [3].

Thailand is the second largest energy consumer in ASEAN. It is largely depends on energy resources imports [4].

Malaysia is the third largest energy consumer in ASEAN. It is largest exporter of LNG, until recently exported oil, but since 2012 it has become an importer and dynamically increases the volume of oil imports [5].

Singapore is a key node of trade and oil refining in ASEAN. It is entirely depends on external supplies of primary energy resources (oil, natural gas) [6].

Vietnam has significant resources of renewable energy, fully satisfies their needs by its own coal, gas and oil almost completely. Vietnam actively develops nuclear power and oil refining [7].

Philippines consume only its own natural gas, are completely depends on imports of oil and partly on imported coal. In this country rapidly grows electricity demand [8].

Myanmar has rich resources of gas and significant hydropower potential. Great potential for growth in energy consumption in the country is necessary for economic growth and improving living standards [9].

Laos has significant plans to develop hydropower on Mekong River and characterized by the growth of electricity exports. But construction of hydroelectric power stations on the Mekong River, which flows around the peninsula of Indochina, will reduce the amount of fish that is a staple in the diet of the inhabitants of Laos, Thailand, Cambodia and Vietnam. This will force more to raise cattle, increased costs of water, which is very difficult for these countries and for their nature, according to the World Wildlife Fund [10,11].

Cambodia is characterized by a low level of electrification. There is potential for the detection of oil and gas reserves in Cambodia [12].

Brunei is one of the first in Asia in terms of life. Base of its economics are oil and natural gas. Exports of this resources generates for about $60 \%$ of Brunei GDP [13].

\section{Expected demand for primary energy in ASEAN}

According to the New Policies Scenario, primary energy consumption in ASEAN by 2035 could increase by almost $80 \%$ compared with the current year and will be about 1 billion toe, Table 9. The growth rate slows progressively from an average of $3 \%$ per year to 2020 to $2.3 \%$ per year from 2020 to 2035, largely reflecting a gradual decline in economic and population 
growth rates, plus results from policy efforts to move towards more efficient patterns of energy use. The region remains heavily dependent on fossil fuels, which collectively represent $80 \%$ of primary energy demand in 2035 .

Table 9. Primary energy demand in the ASEAN countries for the period until 2035, Mtoe. Based on [2]

\begin{tabular}{|l|c|c|c|c|c|}
\hline & $\mathbf{2 0 1 3}$ & $\mathbf{2 0 1 6}$ & $\mathbf{2 0 2 0}$ & $\mathbf{2 0 2 5}$ & $\mathbf{2 0 3 5}$ \\
\hline Indonesia & 222 & 232 & 255 & 285 & 360 \\
\hline Malaysia & 83 & 101 & 95 & 110 & 130 \\
\hline Philippines & 46 & 55 & 60 & 70 & 95 \\
\hline Thailand & 137 & 147 & 150 & 170 & 210 \\
\hline Rest of ASEAN & 152 & 155 & 160 & 180 & 220 \\
\hline Total ASEAN & $\mathbf{6 4 0}$ & $\mathbf{6 9 0}$ & $\mathbf{7 1 8}$ & $\mathbf{8 0 4}$ & $\mathbf{1 0 0 4}$ \\
\hline
\end{tabular}

Table 9 and Fig. 3 show that in general the consumption of primary energy in the region from 2013 until 2035 could grow by almost $60 \%$. It is important to note that the volume of use of nuclear energy, hydropower, bioenergy and other renewable energy resources is increasing very moderately. In 2035 in total, these resources will not take more than $20 \%$ of total primary energy consumption in the region. Accordingly, the consumption of oil, gas and coal, according to the construction of scenarios, grows rapidly and can reach an $80 \%$ (today - $72 \%$ ) in the total primary energy consumption.

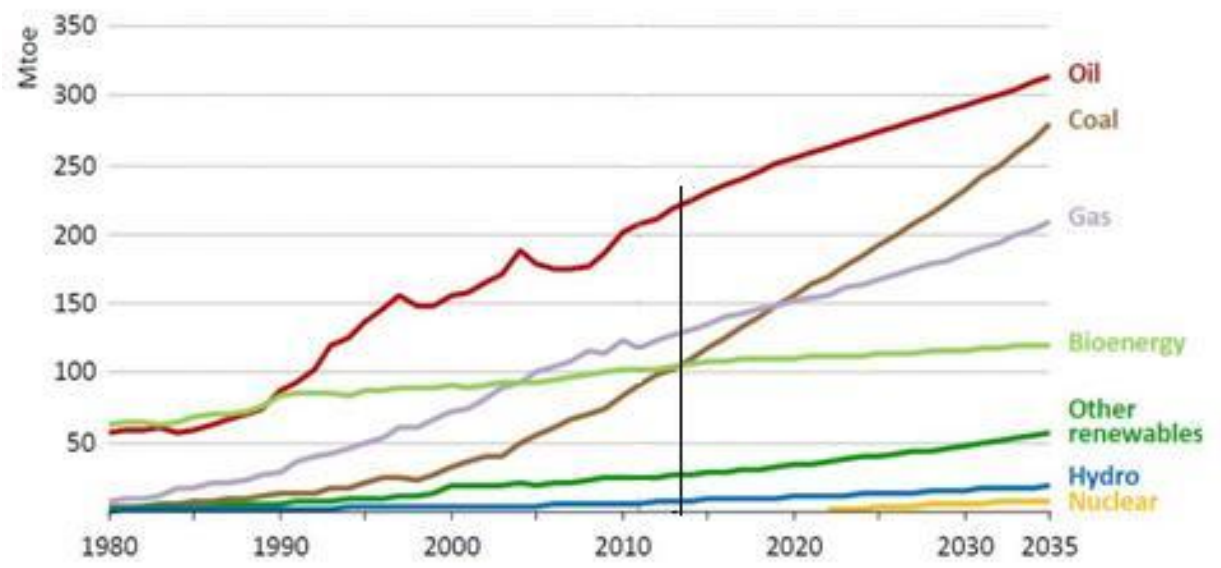

Fig 3. ASEAN primary energy demand by source [2]

About nonrenewable energy resources in this case we can say the following. Oil consumption in the region during the analyzed period (by 2035) may increase by 1.5 times. As before, the oil will hold the largest share in the primary energy consumption in the region.

Coal demand triples, growing at $4.8 \%$ per year on average over the projection period. It overtakes natural gas from 2020 to become the second-largest component of Southeast Asia's energy mix, coal's share reaching $28 \%$ in 2035 . This rapid increase in the share of coal in primary energy consumption, of course, should be explained by the availability of sufficient stocks of coal production (especially in Indonesia) and by logical desire to replace part of consumed oil and natural gas on that coal especially for new capacities.

Natural gas consumption in the region could rise to $220 \mathrm{bcm}$ in 2035 increased compared to the present day by almost $70 \%$. The share of its total consumption of primary energy will remain until the same level (about 20\%). This is explained by the rather high price of local 
natural gas and LNG imported into the region. Perhaps the situation will change with the increasing demands on the limitation of emissions of carbon dioxide, which will slow down the consumption of coal in favor of gas.

The share of renewables (including traditional biomass) in Southeast Asia's primary energy demand falls from $28 \%$ in 2013 to $20 \%$ in 2035 . This results from a large shift away from the use of traditional biomass (mostly fuel wood, charcoal, animal dung and agricultural residues used for household cooking and water heating) in favour of modern fuels, which is driven by rising living standards and ongoing urban migration. The share of traditional biomass in the region's primary energy demand drops from $11 \%$ in 2013 to $6 \%$ in 2035 . Countering this trend is growth in demand for modern renewables - including geothermal, hydro, wind, solar and modern biomass.

Nuclear power does not currently feature in the energy mix of any Southeast Asian country. There is concern about the future of energy security, and accordingly there are plans to enter the nuclear power plant in Vietnam, Thailand, but it will be after 2020.

Now we can consider the possible trends in the energy development of some ASEAN countries from the positions of energy security.

Indonesia. In the New Policies Scenario, Indonesia's total primary energy demand growth averages $2.5 \%$ per year over 2013-2035, rising from 222 Mtoe to nearly 360 Mtoe, Table 10. Over the period, its population expands from 242 million to 302 million and its economy grows by around $220 \%$.

Table 10. Primary energy demand in Indonesia by fuel (Mtoe). Based on [2]

\begin{tabular}{|l|c|c|c|c|c|}
\hline & $\mathbf{2 0 1 3}$ & $\mathbf{2 0 1 6}$ & $\mathbf{2 0 2 0}$ & $\mathbf{2 0 2 5}$ & $\mathbf{2 0 3 5}$ \\
\hline Coal & 54 & 63 & 60 & 78 & 115 \\
\hline Oil & 74 & 73 & 84 & 87 & 95 \\
\hline Gas & 35 & 34 & 46 & 53 & 71 \\
\hline Hydro & 3,5 & 3,3 & 3,5 & 3,6 & 3,7 \\
\hline Bioenergy* & 40 & 40 & 39 & 37 & 38 \\
\hline Other renewables & 16 & 19 & 21 & 25 & 37 \\
\hline Total & $\mathbf{2 2 2}$ & $\mathbf{2 3 2}$ & $\mathbf{2 5 5}$ & $\mathbf{2 8 5}$ & $\mathbf{3 6 0}$ \\
\hline
\end{tabular}

* Includes traditional and modern biomass uses.

When analyzing the prospects for energy development in Indonesia (tab. 10), and also taking into account the already existing situation (Table. 5, 6, 8), you can see the following trends. Coal consumption by 2035 compared to 2013 should grow by 2.1 times, it is justified in terms of energy security because of the substantial reserves of the country for its production. Gas consumption during this period should also grow to 2 times. Now Indonesia has its own natural gas, but for the last three years, the volume of its production decreased by $14 \%$. If such dynamics continues, by 2025 Indonesia will become a country - importer of natural gas. As for oil, in the last three years its production in the country has decreased by $12 \%$, while consumption grew by $11 \%$. Dependence on imported oil in Indonesia has increased during that time from $27 \%$ to $42 \%$. Till 2035 oil consumption in Indonesia will increase by $28 \%$. At the same time, the share of renewable energy in the structure of primary energy consumption can be reduced up to $20 \%$ in 2035 against $25 \%$ now. Emerging trends will lead to the need for import of natural gas, to an even greater dependence on oil imports and in general on energy imports, to reducing the possibility of future energy security providing.

Thailand. In the New Policies Scenario, Thai primary energy demand grows at $2.3 \%$ on average per year between 2013 and 2035, for an overall rise of 75\% (Table 11). Key drivers include ongoing urbanization and a near tripling in the size of its economy. Per-capita energy use continues to increase, reaching 3 toe in 2035. 
Table 11. Primary energy demand in Thailand by fuel (Mtoe). Based on [2]

\begin{tabular}{|l|c|c|c|c|c|}
\hline & 2013 & 2016 & 2020 & 2025 & 2035 \\
\hline Coal & 16 & 18 & 28 & 34 & 47 \\
\hline Oil & 50 & 59 & 61 & 63 & 74 \\
\hline Gas & 47 & 44 & 48 & 50 & 51 \\
\hline Nuclear & - & - & - & - & 2 \\
\hline Hydro & 1,3 & 0,8 & 1,3 & 1,4 & 1,5 \\
\hline Bioenergy & 22 & 23 & 26 & 27 & 30 \\
\hline Other renewables & 0,2 & 2,8 & 0,2 & 0,5 & 0,9 \\
\hline Total & $\mathbf{1 3 7}$ & $\mathbf{1 4 7}$ & $\mathbf{1 6 0}$ & $\mathbf{1 8 0}$ & $\mathbf{2 1 0}$ \\
\hline
\end{tabular}

Prospects of energy consumption development of Thailand (tab. 11), and already existing trends (Table. 5, 6, 8) show the following situation. Coal consumption by 2035 compared to 2013 should grow by almost 3 times, but dependence on imported coal in Thailand is already at $70 \%$. Gas consumption for this period may grow by $9 \%$. Gas production in the country is growing (for the last 3 years growth of its production was $15 \%$ ), but even more rapidly growing demand for natural gas $(17 \%$ for the same 3 years). Current dependence on gas imports in Thailand is about $20 \%$ and it seems that this level of dependence will persist and continue. As for oil, in the last three years, the country's dependence on its imports remained at $67 \%$. By 2035, the country's oil demand may rise more in the half. At the same time, the share of renewable energy in the total primary energy consumption could fall from $17 \%$ to $15 \%$. Positive expectations are connected to input nuclear electricity generation capacity by 2030 (if it happens). In general, emerging trends gradually lead the country to a further increase dependence on energy imports, reducing the possibility of providing perspective energy security.

Philippines. In the New Policies Scenario, primary energy demand in the Philippines doubles by around 2030 and then rises further to 92 Mtoe in 2035, at a growth rate of $3.5 \%$ per year on average (Table 12).

Table 12. Primary energy demand in Philippines by fuel (Mtoe). Based on [2]

\begin{tabular}{|l|c|c|c|c|c|}
\hline & 2013 & 2016 & 2020 & 2025 & 2035 \\
\hline Coal & 11 & 13 & 16 & 20 & 28 \\
\hline Oil & 14 & 20 & 21 & 25 & 28 \\
\hline Gas & 3 & 3 & 5 & 6 & 9 \\
\hline Hydro & 2,2 & 2,1 & 2,4 & 2,6 & 3 \\
\hline Bioenergy & 7 & 7 & 8 & 8 & 8 \\
\hline Other renewables & 9 & 10 & 12 & 14 & 18 \\
\hline Total & $\mathbf{4 6}$ & $\mathbf{5 5}$ & $\mathbf{6 0}$ & $\mathbf{7 5}$ & $\mathbf{9 5}$ \\
\hline
\end{tabular}

Prospects of energy consumption development of the Philippines (tab. 12), and also already existing trends (Table. $5,6,8$ ) shows the following features. Coal consumption by 2035 compared to 2013 should grow by 2.5 times. The volume of coal production in the country is insufficient, but coal consumption of the past three years has increased by $36 \%$. Dependence on imported coal in the country is already at 50\%. Gas consumption for this period can grow three times. At the same time, it is unclear what volume of gas production can the Philippines reach during the analyzed period. While the country is consumed only own gas that is produced there. As for oil, its production is relatively small but in the last three years its consumption was steadily increased. By the end of 2013, the dependence on imported oil in the country was $91 \%$. By 2035 , the country's oil demand may rise twice. The 
share of renewable energy in the total primary energy consumption, are likely to remain at the same level (29-30\%). In general, emerging trends gradually lead the country to a further increase dependence on energy imports, to reducing of the opportunities for providing of energy security.

Malaysia. In the New Policies Scenario, Malaysia's primary energy demand may increase of $57 \%$ in 2013-2035 with annual average growth of 2.3\% (Table 13). Growth in demand slows over time as growth in population and GDP moderate. Malaysia's per-capita energy consumption is currently relatively high for the region, at $61 \%$ of the OECD average.

Table 13. Primary energy demand in Malaysia by fuel (Mtoe). Based on [2]

\begin{tabular}{|l|c|c|c|c|c|}
\hline & 2013 & 2016 & 2020 & 2025 & 2035 \\
\hline Coal & 17 & 20 & 25 & 30 & 35 \\
\hline Oil & 31 & 36 & 37 & 38 & 40 \\
\hline Gas & 31 & 39 & 40 & 42 & 45 \\
\hline Hydro & 2,1 & 4,2 & 4,3 & 4,7 & 4,9 \\
\hline Bioenergy & 2,2 & 2,3 & 2,8 & 3,2 & 4,4 \\
\hline Other renewables & 0,0 & 0,3 & 0,9 & 0,9 & 1,0 \\
\hline Total & $\mathbf{8 3}$ & $\mathbf{1 0 1}$ & $\mathbf{1 1 0}$ & $\mathbf{1 1 8}$ & $\mathbf{1 3 0}$ \\
\hline
\end{tabular}

When analyzing the prospects for energy development of Malaysia (tab. 13), and the current trends (Table. 5, 6, 8) we can see the following features. Coal consumption by 2035 compared to 2013 should grow by 2.3 times. The volume of coal production in the country is insufficient, but the consumption of the past three years has increased by $15 \%$. Dependence on imported coal in the country is already at $90 \%$. Gas consumption for this period could grow by $30 \%$, which could be covered by own sources of natural gas. As for oil, over the past three years with declining oil production and increasing consumption Malaysia moved into oil importer status. By the end of 2013, the dependence on imported oil in the country amounted to $5 \%$. By 2035, the country's oil demand may rise 1.3 times. The share of renewable energy in the total primary energy consumption, are likely to remain at the same level $(5-6 \%)$. In general, emerging trends gradually lead the country to a further increase dependence on energy imports, to reducing of the opportunities to provide energy security of the country.

\section{Expected production of primary energy in ASEAN}

In the New Policies Scenario, the outlook for fuel production varies by fuel and by country (fuel-by-fuel discussion follows). Southeast Asia's oil production falls by nearly one-third, from 2.5 million barrels per day (mb/d) in 2012 to $1.7 \mathrm{mb} / \mathrm{d}$ in 2035 , with continued decline across the region's big mature oil fields (Figure 3.2). Prospects for gas production are brighter because of a larger base of remaining resources and strengthening demand across the AsiaPacific market. Gas production in Southeast Asia increases from $203 \mathrm{bcm}$ in 2011 to about $260 \mathrm{bcm}$ in 2035, though growth slows after 2020. The region's coal output continues to expand, led by Indonesia, to meet fast-increasing domestic demand and export growth (though this occurs mainly in the medium term). ASEAN coal production increases from 348 Mtce in 2011 to around 620 Mtce in 2035. 4).

Now we can consider the possible prospects of fossil fuels production in the region (Fig. 

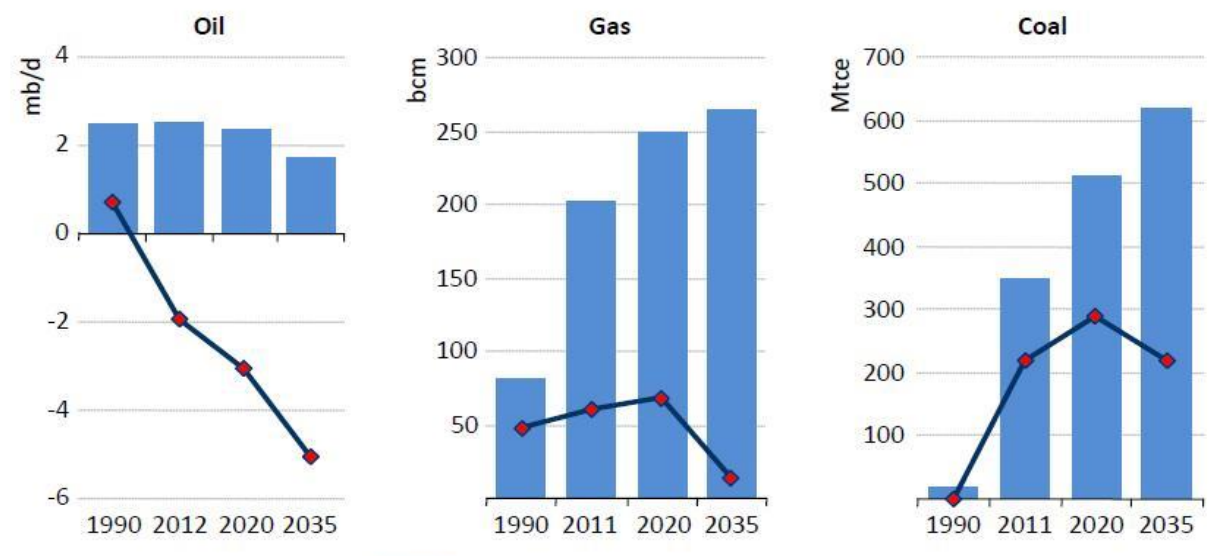

* Positive values are exports; negative values are imports.

Fig. 4. ASEAN fossil fuel production and net trade [2].

The fig. 4 shows that oil production will decline and by 2035 will fall to $1.7 \mathrm{mb} / \mathrm{d}$ ( 80 mtoe per year). This drop is due to a reduction in oil production on old oil fields. Taking into account the plans for oil consumption in 2035 , by this time the region will has to import for about $5 \mathrm{mb} / \mathrm{d}$ of oil (240 mtoe per year).

Significant gas reserves in deposits of the region allow to hope for a significant increase in gas production by 2035 - about $260 \mathrm{bcm}$ (235 mtoe) per year. Taking into account the plans for gas consumption in the region in 2035, the net gas exports could reach around 15 bcm (13-14 mtoe) per year.

According to the Scenario coal mining will actively develop in the ASEAN (Indonesia first of all). By 2035, the whole region should produce some 620 Mtce of coal (380 mtoe) per year. Taking into account the plans for coal consumption in the region in 2035, the net coal exports can be about 210 mtce (140 mtoe) per year.

Thus, the analysis of long-term consumption of primary energy and analysis of long-term production of this energy (Scenarios of new policies) let us make the following conclusions.

\section{Conclusions}

Despite attempts to increase the share of renewable energy in primary energy consumption structure, this share is reduced and by 2035 could reach only $20 \%$.

ASEAN by 2035 will be $75 \%$ dependent on oil imports, but his own needs will be met by natural gas and coal. Turning to individual countries, we can say that all countries, except Brunei, will be significantly dependent on external oil supplies. All countries except Malaysia, Indonesia, Vietnam and Brunei will depend on external supplies of natural gas. All countries except Indonesia and Singapore, will be dependent on external supplies of coal. There are significant risks associated with the containment of nuclear power development (anti-nuclear sentiment in the world).

These challenges to the energy security of the ASEAN countries can be reduced only by a radical increase in the share of renewable energy in the structure of primary energy consumption, particularly in countries heavily dependent on energy imports.

In regard to oil, the strong dependence of the region on oil can be reduced only through the active increasing of the usage of biofuels, electric or hybrid vehicles. 


\section{References}

1. BP Statistical Review of World Energy, (June 2017). Available: http://www.bp.com [Accessed 10 September 2017]

2. Southeast Asia Energy Outlook. World Energy Outlook Special Report, (2013). Available: http:// www.iea.org [Accessed 18 September 2017]

3. Energy Policies Beyond IEA Countries - Indonesia, (2015). Available: http://www.iea.org [Accessed 10 September 2017]

4. World Energy Outlook Special Report on Southeast Asia, (2015). Available: http://www.iea.org [Accessed 12 September 2017]

5. Malaysia Energy Statistics. Available: http://www.iea.org [Accessed 5 May 2017]

6. Singapore Energy Statistics. Available: http://www.iea.org [Accessed 10 May 2017]

7. Vietnam Energy Statistics. Available: http://www-pub.iaea.org [Accessed 10 September 2017]

8. Philippines Energy Statistics. Available: http://www.iea.org [Accessed 12 May 2017]

9. Myanmar Energy Statistics. Available: http://www.iea.org [Accessed 5 May 2017]

10. Future energy demand in Laos, (2012). Available: http://www.utu.fi [Accessed 18 August 2017]

11. The construction of a hydropower plant on the Mekong River in Indochina will deprive local fish residents, (2012). Available: http://ria.ru [Accessed 5 May 2017]

12. Cambodia Energy Sector Strategy. Available: http://www.un.org [Accessed 5 May 2017]

13. ASEM Ministerial Conference on Energy Security - Brunei. Available: https://eeas.europa.eu [Accessed 12 August 2017] 